\title{
Antidiarrhoeal activity of Aristolochia argentina Gris. (Aristolochiaceae) in rodents
}

\author{
Jésica D. Paredes ${ }^{1, *}$, Ángela Sosa ${ }^{2}$, María Fusco ${ }^{2}$, Mauricio R. Teves ${ }^{1}$, Graciela H. Wendel ${ }^{1}$, Lilian E. Pelzer ${ }^{1}$ \\ ${ }^{1}$ Farmacología, ${ }^{2}$ Farmacognosia, Departamento de Farmacia, Facultad de Química, Bioquímica y Farmacia, Universidad Nacional de San Luis, San Luis, \\ Argentina.
}

\begin{tabular}{|c|c|}
\hline ARTICLE INFO & ABSTRACT \\
\hline $\begin{array}{l}\text { Article history: } \\
\text { Received on: } 23 / 11 / 2015 \\
\text { Revised on: } 18 / 12 / 2015 \\
\text { Accepted on: } 03 / 01 / 2016 \\
\text { Available online: } 27 / 02 / 2016\end{array}$ & $\begin{array}{l}\text { The roots of Aristolochia argentina are used in folk medicine for the treatment of colitis, diarrhoea and } \\
\text { hemorrhoids. In this study, based on ethnobotanical lead, we evaluated the antidiarrhoeal activity of Aristolochia } \\
\text { argentina lyophilized aqueous extract (AALE) in rats and mice using various models. The castor oil and } \\
\text { magnesium sulphate induced diarrhoea, the small intestinal transit in mice and the intestinal fluid accumulation } \\
\text { were used in this study. At the doses of } 62.5,125 \text { and } 250 \mathrm{mg} / \mathrm{kg} \text { p.o., the AALE showed significant }\end{array}$ \\
\hline $\begin{array}{l}\text { Key words: } \\
\text { Antidiarrhoeal, Aristolochia } \\
\text { argentina, Aristolochiaceae, } \\
\text { Intestinal transit, Intestinal } \\
\text { fluid accumulation. }\end{array}$ & $\begin{array}{l}\text { castor oil induced enteropooling. AALE delays small intestinal transit possibly, at least in part, involving opioid } \\
\text { and } \alpha_{2} \text {-adrenergic receptors. The phytochemical analysis revealed the presence of carbohydrates, flavonoids, } \\
\text { tannins, saponins and anthraquinones. The results suggest that AALE showed antidiarrhoeal activity by inhibiting } \\
\text { intestinal motility and enteropooling property, justify its use in traditional medicine. }\end{array}$ \\
\hline
\end{tabular}

\section{INTRODUCTION}

Aristolochia is a genus native to South America, in Argentine is represented by 21 species (Jaime et al., 2006), among which Aristolochia argentina grows in the following Argentine provinces: Catamarca, Chaco, Córdoba, Jujuy, La Rioja, Misiones, Salta, San Juan, San Luis, Tucumán (de la Peña and Pensiero, 2004; Dimitri, 2004; Barboza et al., 2009). Aristolochia argentina Gris. (Aristolochiaceae) is popularly known as "Charrúa", "Charruga", "Patito", "Buche de pavo" (de la Peña and Pensiero, 2004). The roots of this plant are used in folk medicine and are commercially available. The infusions and tinctures are used mainly for the treatment of colitis, diarrhoea and hemorrhoids (Priestap et al., 2003). Traditionally, has been used as antirheumatic, emmenagogue, diuretic, diaphoretic, antidiarrhoeal and antihemorrhoids (Hieronymus, 1882; Saggesse et al., 1959; Ratera and Ratera, 1980; Martinez et al., 2005; Arias Toledo et al., 2007, 2009; Arias Toledo, 2009; Barboza et al., 2006, 2009; Trillo et al., 2010; Ceballos et al., 2014).

\footnotetext{
* Corresponding Author

Jésica D. Paredes. Farmacología. Facultad de Química, Bioquímica y Farmacia, Universidad Nacional de San Luis, Chacabuco y Pedernera (5700) San Luis. Argentina. Phone: +54-266-4520300- Interno 6162. E-mail: jdparedes@unsl.edu.ar
}

Externally can be used for dermatological treatments, as antiseptic, and for treating poisoning and pruritus (Barboza et al., 2009; Hieronymus, 1882). Extracts of Aristolochia argentina also showed antibacterial and antifungal activities (Gutkin et al., 1981). Diarrhoea is defined as having loose or watery stools at least three times per day, or more frequently than normal for an individual. Though most episodes of childhood diarrhoea are mild, acute cases can lead to significant fluid loss and dehydration, which may result in death or other severe consequences if fluids are not replaced at the first sign of diarrhoea. Diarrhoea can be caused by an increased osmotic load within the intestine resulting in retention of water within the lumen; excessive secretion of electrolytes and water into the intestinal lumen; exudation of protein and fluid from the mucosa; and altered intestinal motility resulting in rapid transit and decreased fluid absorption (Shakey and Wallace, 2012). Diarrhoea is considered as one of the leading causes of growth retardation and death in infants (Petri et al., 2008). Diarrhoea remains the second leading cause of death among children under five globally. Nearly one in five child deaths - about 1.5 million each year - is due to diarrhoea. It kills more young children than AIDS, malaria and measles combined. Each year, an estimated 2.5 billion cases of diarrhoea occur among children under five years of age, and estimates suggest that overall incidence has remained relatively stable over the past two decades (UNICEF/WHO, 2009). 
In recent years there has been great interest in herbal medicines for treating all kinds of diseases, including diarrhoea. Medicinal herbs constitute an indispensable component of the traditional medicine practiced worldwide due to the economic viability, accessibility and ancestral experience. The plant remedies or naturally products are known to contain synergistic and/or side effects neutralizing potentials, and usually offer their pharmacological actions mediated through multiple patways (Gilani and Rahman, 2005). There are numerous studies that report the antidiarrhoeal activity of plant extracts, prepared with varied parts of them, in different parts of the world (e.g., Mujumdar et al., 2005; Jia et al., 2008; Mazzolin et al., 2010: Awe et al., 2011; Nansunga et al., 2014). There is no scientific proof justifying the traditional use of Aristolochia argentina root in the treatment of diarrhoea. This study was conducted to investigate the possible usefulness of the roots of Aristolochia argentina in the treatment of diarrhoea.

\section{MATERIALS AND METHODS}

\section{Plant material}

Roots of Aristolochia argentina were collected in the San Luis province, Ayacucho Department, Luján locality. The botanical identification of specie was made through the application of classical taxonomic methods and certified by Dr. Luis Del Vitto. For future reference, the voucher specimen was deposited in the Herbarium of the Universidad Nacional de San Luis, San Luis, Argentina, under the registry No. 9258. The collection of plant material was approved by the chief of "Biodiversity" program, Ministry Environment of the government of San Luis province (Resolution No 588-PBD-2014).

\section{Extraction procedure}

The roots collected were cleaned, selected and desiccated, and then the dry material was mechanically milled to powder. Infusion of roots of the plant at $10 \%$ was prepared according to VI Ed Argentine National Pharmacopoeia. The plant material was separated by filtration and the aqueous extract was concentrated and lyophilized to preserve it.

\section{Preliminary phytochemical screening}

Chemical tests were carried out on aqueous extract of the roots of Aristolochia argentina using standard procedures, to identify their major groups of chemical constituents.

\section{Animals}

Adult albino Wistar rats (150-180 g) and mice (20-25 g) were used. They were housed in standard environmental conditions and fed with rodent diet and water ad libitum. The animals were housed at a room temperature of $24 \pm 1^{\circ} \mathrm{C}$ with $12 \mathrm{~h}$ light/dark cycle. The animals were randomly assigned to different groups and a period of 4 days was allowed to adapt to each experiment. All experiments were in compliance with the ANMAT No. 6344/96 for animal care guidelines. Experimental protocols were approved by Animal Care and Use Institutional
Committe (CICUA) of Facultad de Química, Bioquímica y Farmacia, Universidad Nacional de San Luis (approval numbers, F-101/12, Res. N ${ }^{\circ}$ 1498/13; F-145/13, F-146/13, F-167/13, Res. $\left.\mathrm{N}^{\circ} 10 / 14\right)$.

\section{Acute toxicity test}

The Aristolochia argentina lyophilized extract (AALE) was studied for acute oral toxicity as per revised OECD guidelines No. 423. Thirty albino mice $(20-25 \mathrm{~g})$ of both sexes were randomly divided into five groups of six animals each. The mice were fed on mice pellets and water ad libitum. The animals were starved for $4 \mathrm{~h}$ prior to testing. The AALE was re-dissolved in distilled water and administered intragastrically (5, 50, 300 and $2000 \mathrm{mg} / \mathrm{kg}$ ). The fifth group, served as control, was treated only the vehicle (distilled water). The volume of the AALE were administered to each animal in the test group was calculated based on the body weight $(0.2 \mathrm{ml} / \mathrm{mice})$. Animals were observed daily, for 14 days. The parameters studied were body weight and macroscopic analysis of the vital organs: heart, lungs, liver, spleen and kidneys.

\section{Normal defaecation}

The test performed in mice according to Izzo et al. (1992). Four groups of 6 mice each, starved for 18 h, were placed individually in polythene cages with filter paper at the bottom. AALE (125 and $250 \mathrm{mg} / \mathrm{kg}$ ) was administered to two groups, loperamide $(10 \mathrm{mg} / \mathrm{kg})$ to another, while the fourth group, served as control, was treated only the vehicle (distilled water). The total number of faeces in each group was counted every $h$ for the next 3 $\mathrm{h}$. The percent reduction in the number of faeces in the treated group was obtained by comparison with the control animals.

\section{Castor oil-induced diarrhoea in mice}

Diarrhoea was induced by oral administration of castor oil to mice ( $0.2 \mathrm{ml} / \mathrm{animal}$ ) (Izzo et al., 1992). Food but not water was withdrawn $12 \mathrm{~h}$ before the experiments. AALE $(62.5,125$ and $250 \mathrm{mg} / \mathrm{kg}$ ) and loperamide $(10 \mathrm{mg} / \mathrm{kg})$, a standard antidiarrhoeal agent, were administered orally $30 \mathrm{~min}$ before castor oil administration. Control mice received the same volume of distilled water. The animals were placed in individual cages over clean filter paper. Mice were scored (double blind) for copious (++), mild (+) or lack ( 0$)$ of diarrhoea, $2 \mathrm{~h}$ after castor oil challenge. The activity score was calculated by taking the sum of the number of "+" mice and twice the number of " ++ " mice. A score of 0 indicated a complete absence of diarrhea (Di Carlo et al., 1993).

\section{Magnesium sulphate induced diarrhoea}

A similar protocol as for castor oil-induced diarrhoea was followed. The mice were divided into different groups for the treatment either with various doses of AALE, vehicle or loperamide. After $30 \mathrm{~min}$ each of these animals was given $2 \mathrm{~g} / \mathrm{kg}$ magnesium sulphate by oral route (De Melo et al., 1988). Mice were scored (double blind) for copious $(++)$, mild $(+)$ or lack $(0)$ of diarrhoea, $4 \mathrm{~h}$ after magnesium sulphate challenge. 


\section{Effect of small intestinal transit in mice}

The effect of AALE on small intestinal transit in mice was tested using the charcoal method (Mascolo et al., 1992). Mice were fasted for $18 \mathrm{~h}$ and pretreated orally with AALE at dose of $62.5,125$ and $250 \mathrm{mg} / \mathrm{kg}$. The charcoal meal (a suspension containing $10 \%$ charcoal in $5 \%$ arabic gum; $0.1 \mathrm{ml} / 10 \mathrm{~g}$ ) was administered $30 \mathrm{~min}$ after the administration of AALE. A control group was established, which was administered the same volume of vehicle (distilled water).

Morphine sulphate $(10 \mathrm{mg} / \mathrm{kg}$, p.o. $)$ was used to reduce gastrointestinal motility (standard drug). Mice were euthanized by cervical dislocation after $20 \mathrm{~min}$ and the small intestine was rapidly removed and laid out on white filter paper for inspection and measurement of distances traversed by the charcoal. The length traversed by the charcoal marker was calculated as a percentage of the intestine length.

To obtain information about the mechanism of action of AALE $(250 \mathrm{mg} / \mathrm{kg})$, we experienced with different drugs acting by a well know mechanism such as atropine $0.25 \mathrm{mg} / \mathrm{kg}$, phentolamine $1 \mathrm{mg} / \mathrm{kg}$, yohimbine $1 \mathrm{mg} / \mathrm{kg}$, propranolol 2.5 $\mathrm{mg} / \mathrm{kg}$, cyproheptadine $2.5 \mathrm{mg} / \mathrm{kg}$, verapamil $5 \mathrm{mg} / \mathrm{kg}$, and naloxone $10 \mathrm{mg} / \mathrm{kg}$. These drugs were dissolved in $0.9 \% \mathrm{NaCl}$ (saline) and given subcutaneously $10 \mathrm{~min}$ before extract administration, with the exception of verapamil, yohimbine, and naloxone given intraperitoneally (Di Carlo et al., 1993, Capasso et al., 2004).

\section{Intestinal fluid accumulation}

The method is based on that of Robert et al. (1976), that evaluate the net accumulation of fluid in the lumen of the small intestine. The rats were fasted for $12 \mathrm{~h}$ before the experiment. AALE $(62.5,125$ and $250 \mathrm{mg} / \mathrm{kg}$ ) was administered (p.o.) to rats, followed $1 \mathrm{~h}$ later by castor oil ( $2 \mathrm{ml} / \mathrm{rat})$. Control rats received only vehicle. The standard chlorpromazine $(30 \mathrm{mg} / \mathrm{kg}$, i.p.) was administered $30 \mathrm{~min}$ before the oral administration of castor oil. The animals were euthanized by inhalation of carbon dioxide, 30 min later.

The small intestine was clamped at the pyloric valve and the ilio-caecal juntion and carefully removed from the abdomen. The small intestine was weighed $\left(W_{l}\right)$, emptied of fluid, reweighed $\left(W_{2}\right)$ and the length $(L)$ measured. The difference in weight divided by the length shows the "enteropooling" in milligrams of fluid per centimeter of intestine (Valle et al., 2000).

$$
\text { Enteropooling }=\left(W_{1}-W_{2}\right) / L
$$

\section{Statistical analysis}

Diarrhoea was expressed as total score and the chi-square test was used to determine the significance between groups. Intestinal fluid accumulation and small intestinal transit were expressed as means \pm S.E.M. and Student's t-test was used to determine the significance of difference between means. A $P$ value less than 0.05 was taken as statistically significant.

\section{RESULTS}

The present study was designed to investigate the antidiarrhoeal properties of the A. argentina. Thus, four experimental models (the castor oil and magnesium sulphate induced diarrhoea, the small intestinal transit in mice and the intestinal fluid accumulation) were used, which are applied because they are very simple and reproducible.

\section{Phytochemical screening}

The phytochemical analysis of the aqueous root extracts of A. argentina revealed the presence of, carbohydrates, flavonoids, tannins, saponins and anthraquinones.

\section{Acute toxicity test}

Acute toxicological studies have showed that an oral administration of $2000 \mathrm{mg} / \mathrm{Kg}$ of AALE did not produce any sign of acute toxicity in the animals (male and female). Over the 14 days following the oral administration of AALE, none of the animals died and no significant changes in daily body weight or organ weight were observed through the end of this period (data not shown).

\section{Normal defaecation}

The results of the AALE effect on normal defaecation show that doses of 125 and $250 \mathrm{mg} / \mathrm{kg}$ in an average time of $3 \mathrm{~h}$, normal defaecation was inhibited by 27.78 and $44.45 \%$, respectively, and for loperamide by $72.23 \%$. After $3 \mathrm{~h}$, this inhibitory effect could not be detected as there was no defaecation in the control group after this time, and thus, no comparison could be made.

\section{Castor oil-induced diarrhoea in mice}

All mice in the control group produced copious diarrhoea (total score 12). In the castor oil-induced diarrhoeal experiment in mice, AALE, at the doses of $62.5,125$ and $250 \mathrm{mg} / \mathrm{kg}$ reduced its cathartic effect (Table 1). These results were shown to be statistically significant.

Table 1: Effect of AALE on castor oil-induced diarrhoea in mice.

\begin{tabular}{|c|c|c|c|c|c|}
\hline \multirow{2}{*}{ Treatment } & \multirow{2}{*}{ Dose (mg/kg) } & \multicolumn{3}{|c|}{ Diarrhoea score } & \multirow{2}{*}{$\begin{array}{l}\text { Total score } \\
(\mathbf{m a x}=12)\end{array}$} \\
\hline & & ++ & + & 0 & \\
\hline Castor oil (control) & - & 6 & 0 & 0 & 12 \\
\hline Loperamide & 10 & 0 & 3 & 3 & $3^{\mathrm{b}}$ \\
\hline AALE & 62.5 & 2 & 2 & 2 & $6^{\mathrm{a}}$ \\
\hline AALE & 125 & 2 & 2 & 2 & $6^{\mathrm{a}}$ \\
\hline AALE & 250 & 0 & 4 & 2 & $4^{\mathrm{b}}$ \\
\hline
\end{tabular}

\section{Magnesium sulphate induced diarrhoea}

In the magnesium sulphate-induced diarrhoeal model in mice, AALE at the above dose levels significantly reduced the extent of diarrhoea in test animals (Table 2). 
Table 2: Effect of AALE on magnesium sulphate-induced diarrhoea in mice.

\begin{tabular}{|c|c|c|c|c|c|}
\hline \multirow[b]{2}{*}{ Treatment } & \multirow[b]{2}{*}{$\begin{array}{c}\text { Dose } \\
(\mathrm{mg} / \mathrm{kg})\end{array}$} & \multicolumn{3}{|c|}{ Diarrhoea score } & \multirow{2}{*}{$\begin{array}{c}\text { Total } \\
\text { score } \\
(\mathrm{max}=12)\end{array}$} \\
\hline & & ++ & + & 0 & \\
\hline Magnesium sulphate (control) & 2000 & 6 & 0 & 0 & 12 \\
\hline Loperamide & 10 & 0 & 3 & 3 & $3^{\mathrm{b}}$ \\
\hline AALE & 62.5 & 1 & 2 & 3 & $4^{\mathrm{a}}$ \\
\hline AALE & 125 & 2 & 2 & 2 & $6^{\mathrm{a}}$ \\
\hline AALE & 250 & 0 & 3 & 3 & $3^{\mathrm{b}}$ \\
\hline
\end{tabular}

AALE (Aristolochia argentina lyophilized extract) and loperamide were administered (p.o.) $30 \mathrm{~min}$ before magnesium sulphate administration. Diarrhoea score was analyzed by Chi square test; ${ }^{\mathrm{a}} P<0.05$ vs control; ${ }^{\mathrm{b}} P<0.01$ vs control. Six animals were used for each group.

\section{Effect of small intestinal transit in mice}

In control animals, the charcoal meal traversed $54.91 \pm$ $1.79 \%$ of the total length of the small intestine. Both AALE and morphine inhibited the intestinal propulsion of charcoal in mice (Fig. 1). The inhibitory effect of AALE on gastrointestinal transit was found to be significant at $250 \mathrm{mg} / \mathrm{kg}$ but not at 62.5 and 125 $\mathrm{mg} / \mathrm{kg}$.

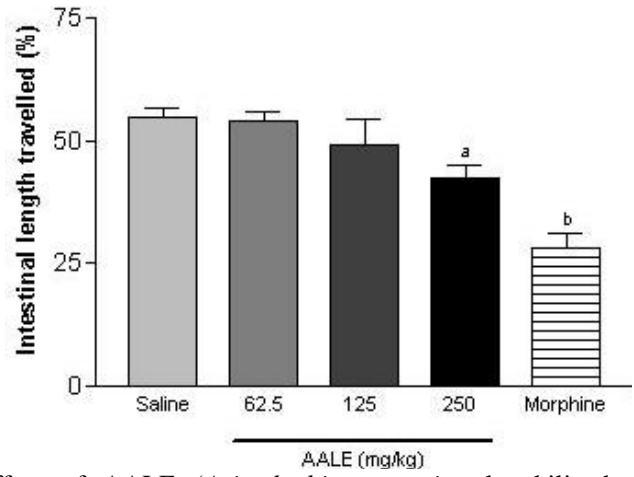

Fig. 1: Effect of AALE (Aristolochia argentina lyophilized extract) on gastrointestinal transit in mice. AALE and morphine $10 \mathrm{mg} / \mathrm{kg}$ were administered (30 $\mathrm{min}$ and $15 \mathrm{~min}$, p.o., respectively) before the charcoal suspension. Results are mean \pm S.E.M. of 6-8 animals for each experiments group. ${ }^{\mathrm{a}} P<0.001,{ }^{\mathrm{b}} P<0.0001$ vs control (Student's $t$-test).

Pretreatment (Fig. 2) with yohimbine, phentolamine and naloxone, but not with propanolol, cyproheptadine or atropine, antagonized the effects the AALE.

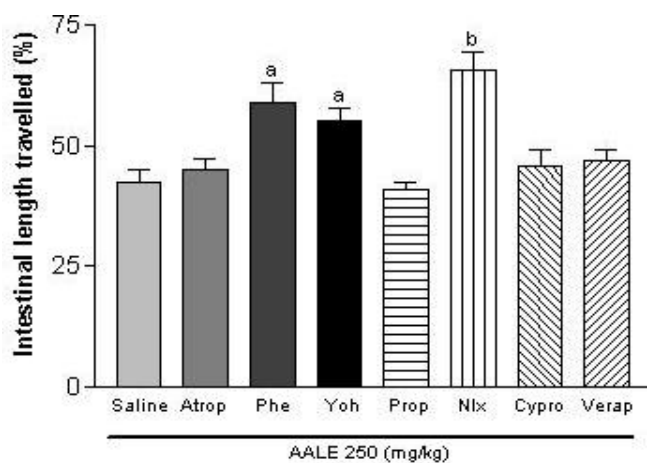

Fig. 2: Effect of AALE (Aristolochia argentina lyophilized extract) (250 $\mathrm{mg} / \mathrm{kg}, p . o$.) on upper gastrointestinal transit alone (saline) or in mice treated (s.c.) with atropine (Atrop, $0.25 \mathrm{mg} / \mathrm{kg}$ ), phentolamine (Phe, $1 \mathrm{mg} / \mathrm{kg}$ ), propanolol (Prop, $2.5 \mathrm{mg} / \mathrm{kg}$ ), and cyprohetadine (Cypro, $2.5 \mathrm{mg} / \mathrm{kg}$ ). Other group was treated (i.p.) with yohimbine (Yoh, $1 \mathrm{mg} / \mathrm{kg}$ ), naloxone (Nlx, 2 $\mathrm{mg} / \mathrm{kg}$ ) and verapamil (Verap, $5 \mathrm{mg} / \mathrm{kg}$ ). Results are mean \pm S.E.M. of $6-8$ animals for each experiments group. ${ }^{\mathrm{a}} P<0.01,{ }^{\mathrm{b}} P<0.001 \mathrm{vs}$ AALE, $250 \mathrm{mg} / \mathrm{kg}$ (Student's $t$-test).

\section{Intestinal fluid accumulation}

Oral administration of castor oil produced accumulation of water and electrolytes in intestinal loop. AALE $(62.5,125$ and $250 \mathrm{mg} / \mathrm{kg}$ ) significantly inhibited castor oil-induced intestinal fluid accumulation in the rats (Fig. 3).

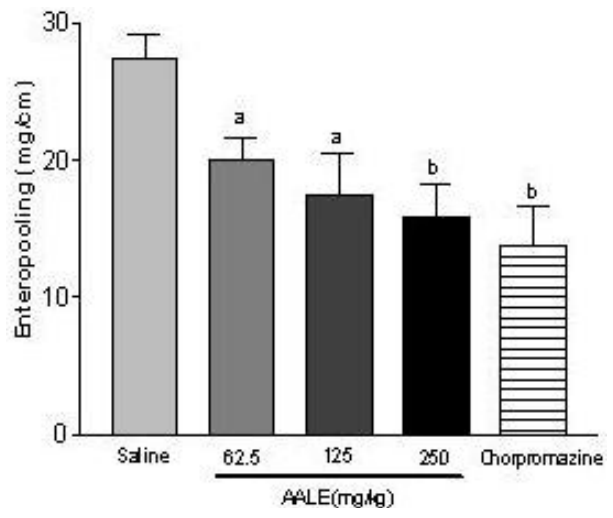

Fig 3: Effect of AALE (Aristolochia argentina lyophilized extract) on intestinal fluid accumulation in rats. AALE was administered (p.o.) to rats, followed $1 \mathrm{~h}$ later by castor oil $(2 \mathrm{ml} / \mathrm{rat})$. The standard chlorpromazine (30 $\mathrm{mg} / \mathrm{kg}$, i.p.) was administered $30 \mathrm{~min}$ before the oral administration of castor oil. Results are mean \pm S.E.M. of 6-8 animals for each experiments group. ${ }^{\mathrm{a}} P<0.01,{ }^{\mathrm{b}} P<0.01$ vs control. (Student's $t$-test).

\section{DISCUSSION}

Diarrhoea is the frequent passage of liquid faeces and it involves both an increase in the motility of the gastrointestinal tract, along with increased secretion and decreased absorption of fluid, and thus a loss of electrolytes (particularly sodium) and water (Rang and Dale, 2008). Hence to restore personal comfort and convenience, many patients require antidiarrhoeal therapy and treatment is carried out to achieve, among other objectives, increased resistance to flow (segmental contraction, decreased propulsion and peristalsis) and increased mucosal absorption or decreased secretion. The use of native plants for the treatment of diarrhea is a common practice in many folk medicines. In this context, the investigation of the antidiarrhoeal effect of AALE in this study comprised the evaluation of its effect on intestinal transit and the fluid accumulation.

Orally administration of AALE up to $2 \mathrm{~g} / \mathrm{kg}$ produced no mortality and visible signs of delayed toxicity 14 days posttreatment. These results ensured the continuance of pharmacological studies on this species using the oral route and motivated us to proceed with the biological assays.

The effect of AALE on experimentally induced diarrhoea was evaluated using castor oil-induced diarrhoea. This is in recognition of the fact that in some diarrhoeas, the secretory component predominates while other diarrhoeas are characterized by hypermotility of the gastrointestinal tract.

Castor oil increase volume of intestinal content by prevention of the re-absorption of water and the liberation of ricinoleic acid, from action of lipases. Ricinoleic acid markedly increased the prostaglandins content in the gut lumen and also caused an increase of the net secretion of the water and electrolytes 
into the small intestine. Also, ricinoleic acid stimulates the production of several mediator substances that include nitric oxide, platelet activating factor, cAMP and tachykinins (Beuoler et al., 1979; Izzo et al., 1990, Mascolo et al., 1992). It has been well known that castor oil causes motility and secretory diarrhoea (Rouf et al., 2003), therefore is a useful model for screening for antimotility and antisecretory compounds. The effect of AALE showed significant antidiarrhoeal activity reducing the castor oilinduced diarrhoea in mice. The highest effect was observed at the dose of $250 \mathrm{mg} / \mathrm{kg}$, which suggest that the antidiarrhoeic activity revolves around this dose. AALE may have brought about this activity by stimulation of the re-absorption of water from the intestinal lumen or by anti-prostaglandin activities that contribute to the pathophysiological functions in the gastrointestinal tract. AALE inhibited the castor oil- induced diarrhoea, it can be assumed that the antidiarrhoeal effect was excerted by antisecretory mechanism. This was also evident from the reduction in enteropooling.

Intraluminal fluid accumulation was determined by castor oil-induced enteropooling. The prevention of intraluminal fluid secretion by AALE in this study may be due to inhibition of prostaglandin biosynthesis with resultant decrease in secretion of fluid into the lumen or may be due to promotion of absorption of water and electrolytes in the gut.

On the other hand, magnesium sulphate has been reported to induce diarrhoea by increasing the volume of intestinal content through prevention of reabsorption of water. It has also been demonstrated that it promotes the liberation of cholecystokinin from the duodenal mucosa, which increases the secretion and motility of small intestine and thereby prevents the reabsorption of sodium chloride and water (Galvez et al., 1993). AALE was found to alleviate the diarrhoeic condition in this model. AALE may have increased the absorption of water and electrolyte from the gastrointestinal tract, since it delayed the gastrointestinal transit in mice as compared to the control. The delay in the gastrointestinal transit prompted by AALE might have contributed, at least to some extent, to their antidiarrhoeal activity by allowing a greater time for absorption. This activity is probably due to the ability of the AALE to inhibit intestinal motility.

The reduction in percentage distance travelled can be used to establish the intestinal smooth muscle relaxation. The property of reducing intestinal contractions (and consequently, intestinal transit) is demonstrated by most antidiarrhoeal drugs and this property was shown by AALE further demonstrating its antidiarrhoeal activity. These conditions tend to suggest that AALE reduced diarrhoea by increasing reabsorption of electrolytes and water or by inhibiting induced intestinal accumulation of fluid just as loperamide. Loperamide acts by decreasing the transit velocity and increasing the capacity of the intestine to retain their fluids, furthermore it inhibits calmodulinsensitive phosphodiesterases (Awouters et al., 1983; Daly and Harper, 2000).

In the evaluation of intestinal transit, morphine was used as standard drug. Morphine and other opiates have been demonstrated to inhibit intestinal transit in vivo and to be spasmolytic in vitro, possibly by an action on neurotransmitter release. Evidence exists for both centrally and peripherally mediated inhibition of intestinal motility by opiates. Thus, opioids may act at more than one site to counteract the pathophysiological basis of diarrhoeal disease. Putative roles for endogenous opiates in control of gastrointestinal motility have been well reviewed by Kromer (1988).

However, the exact mechanism involved is difficult to clarify as control mechanism of intestinal functions are various and imply intrinsic and extrinsic nerves, autacoids and hormones (Di Carlo et al., 1994).

Catcholamines stimulate sodium and chloride absorption from the intestine by interacting with $\alpha_{2}$ adrenergic receptors on enterocytes (Brun et al., 1998), clonidine delays normal small intestinal transit in rat (Ruwart et al., 1980) and inhibits defaecation in basal conditions (Doherty and Hancock, 1985). Also, adrenergic agonists with actions at $\alpha_{2}$-adrenergic receptors promote fluid and electrolyte absorption hence yohimbine, a specific $\alpha_{2}$-receptor antagonist will do the opposite thus promoting diarrhoea (Adeyemi et al., 2008). Our results show that the $\alpha_{2^{-}}$ adrenoreceptor antagonists yohimbine and phentolamine counteracted the effects of AALE on intestinal transit while propranolol, a $\beta$-adrenoceptor antagonist, failed to do so. This indicates a role for the $\alpha_{2}$-adrenergic system in the action of AALE examined.

Atropine, a muscarinic receptor antagonist, inhibits gastrointestinal motility (propulsion), reduces intestinal fluid secretion, and delays gastric emptying thus ameliorating diarrhoea (Adeyemi et al., 2007). In the present study the effect of AALE on intestinal motility was affected by naloxone but unaffected by atropine. Further, 5-hydroxytryptaminergic (cyproheptadine) antagonist did not modify the action of AALE on intestinal transit, indicating that this action did not involve cholinergic and 5hydroxytryptaminergic mediation, but influenced by opioid. This study has demonstrated that AALE delays small intestinal transit possibly, at least in part, involving opioid receptors, which are found in the gastrointestinal wall.

Phytochemical screening of the aqueous extract of Aristolochia argentina revealed the presence of tannins, flavonoids, and saponins. Tannins, flavonoids and other plant metabolites possess antidiarrhoeal activity in different experimental animal models and flavonoids also inhibit diarrhoea induced by castor oil. Tannins are known to reduce secretion and make the intestinal mucus resistant through the formation of protein tannate (Adzu et al., 2003). Di Carlo et al. (1993) demonstrated that flavonoids inhibit intestinal motility and secretion in rodents mediated by $\alpha_{2}$-adrenergic receptors and calcium. These properties may explain the reason for the effective use of the plant as antidiarrhoeal agent in traditional medicine. It is therefore possible that tannins and flavonoids content of Aristolochia argentina among others may be responsible for the antidiarrhoeal activity of AALE. In conclusion, the antidiarrhoeal effect of the AALE may, thus, be attributable to its inhibitory 
action against gastrointestinal motility and the inhibition of enteropooling property. This justifies the use of Aristolochia argentina for the treatment of diarrhoea in traditional medicine.

\section{ACKNOWLEDGEMENTS}

The authors are grateful to animal laboratory technician Mrs. Silvina García Soliman for animal breeding and care. This work was supported by grants from Universidad Nacional de San Luis (CyT, PROICO 2-3014).

\section{REFERENCES}

Adeyemi OO, Akindele AJ. Antidiarrhoeal activity of the ethyl acetate extract of Baphia nitida (Papilionaceae). J Ethnopharmacol, 2007; 116: 407-412.

Adzu B, Amos S, Amizan MB, Gamaniel K. Evaluation of the antidiarrhoeal effects of Zizypus spina-christi stem bark in rats. Acta Tropica, 2003; 87:245-250.

Arias Toledo B. Diversidad de usos, prácticas de recolección y diferencias según género y edad en el uso de plantas medicinales en Córdoba, Argentina. BLACPMA, 2009; 8 (5): 389-401.

Arias Toledo B, Galetto L, Colantonio S. Uso de plantas medicinales y alimenticias según características socioculturales en Villa Los Aromos (Córdoba, Argentina). Kurtziana, 2007; 33 (1):79-88.

Arias Toledo B, Galetto L, Colantonio S. Ethnobotanical knowledge in rural communities of Cordoba (Argentina): the importance of cultural and biogeographical factors. J Ethnobiol Ethnomed, 2009; 5: $40-48$.

Awe E, Kolawole SO, Wakeel KO, Abiodun OO. Antidiarrheal activity of Pyrenacantha studtii Engl. (Iccacinaceae) aqueous leaf extract in rodents. J Ethnopharmacol, 2011; 137: 148-153.

Awouters F, Niemegeers JE, Jansen PAJ. Pharmacology of antidiarrheal drugs. Annu Rev Pharmacol, 1983; 23:279-301.

Barboza GE, Cantero JJ, Núñez C, Ariza Espinar L. 2006. Flora Medicinal de la provincia de Córdoba (Argentina). Museo Botánico Córdoba, Argentina.

Barboza GE, Cantero JJ, Núñez C, Pacciaroni A, Ariza Espinar L. Medicinal plants: A general review and a phytochemical and ethnopharmacological screening of the native Argentine Flora. Kurtziana, 2009; 34 (1-2):7-365.

Beuoler E, Juan H. Effect of ricinoleic acid and other laxatives on net water flux and prostaglandin E release by the rat colon. J Pharm Pharmacol, 1979; 31:61-685.

Brun Y, Wang XP, Willemot $J$, Sevenet $T$, Demenge $P$. Experimental study of antidiarrheal activiy of salicairine. Fundam Clin Pharm, 1998; 12:30-36.

Capasso R, Izzo AA, Capasso F, Romussi G, Bisio A, Mascolo N. A diterpenoid from Salvia cinnabarina inhibits mouse intestinal motility in vivo. Planta Med, 2004; 70:375-377.

Ceballos S, Perea MC. Plantas medicinales utilizadas por la comunidad indígena de Quilmes (Tucumán, Argentina). BLACPMA, $2014 ; 13(1): 47-68$

Daly JW, Harper J. Loperamide: novel effects on capacitative calcium influx. Cell Mol Life Sci, 2000; 57:149-157.

De la Peña MR, Pensiero JF. 2004. Plantas Argentinas: Catálogo de nombres comunes. Buenos Aires, Argentina: L.O.L.A.

De Melo MFF, Thomos G, Mukherjee R. Antidiarrhoeal activity of bisondihydrotoxiferine isolated from de root bark of Strychnos trinervis (Vell.) Mart. (Longaniaceae). J Pharm Pharmacol, 1988; 40:7982.

Di Carlo G, Autore G, Izzo AA, Maiolino P, Mascolo N, Viola $P$, Diurno MV, Capasso F. Inhibition of intestinal motility and secretion by flavonoids in mice and rats: structure-activity relationships. J Pharm Pharmacol, 1993; 45:1054-1059.

Di Carlo G, Mascolo N, Izzo A, Capasso F, Autore G. Effects of quercetin in the gastrointestinal tract in rats and mice. Phytother Res, 1994; 8:42-45.
Dimitri MJ. 2004. Enciclopedia Argentina de Agricultura y Jardinería. Tome I, vol. 2. Buenos Aires, Argentina: ACME AGENCY S.A.C.I. y F.

Doherty N, Hancock A. Role of alpha2-adrenergic reeptors in the control of diarrhea and intestinal motility. J Pharmacol Exp Ther, $1985 ; 225: 269-274$.

Farmacopea Nacional Argentina. 1978. Comisión permanente de la Farmacopea Argentina (6th edn). Ministerio de Salud de la Nación Argentina.

Galvez J, Zarzuelo A, Crespo ME, Lorente MD, Ocete MA, Jimenez J. Antidiarrhoeal activity of Euphorbia hirta extract and isolation of an active flavonoid constituent. Planta Med, 1993; 59: 333 336.

Gilani AH, Rahman A. Trends in ethnopharmacology. J Ethnopharmacol, 2005; 100:43-49.

Gutkind G, Martino V, Graña N, Coussio J, de Torres R. Screening of South American plants for biological activities. I. Antibacterial and antifungal activity. Fitoterapia, 1981; 52:213-218.

Hieronymus J. 1882. Plantae diaphoricae. Florae argentina. Buenos Aires, Argentina.

Izzo AA, Mascolo N, Capasso R, Germano HP, De Pascuele R, Capasso F. Inhibitory effect of cannabinoid agonists on gastric emptying in rat. N-S Arch Pharmacol, 1991; 360:221-223.

Izzo AA, Nicoletti M, Giannattasio M, Capasso F. 1992. Antidiarrhoeal activity of Terminalia sericea Burch ex DC extracts. In: Capasso F, Mascolo N, eds. Natural drugs and the digestive tract. Roma: EMSI 223-230.

Jaime GS, Barboza GE, Vattuone MA. Comparative pharmacobotanic study of argentinean Aristolochias. Mol Med Chem, 2006; 10:43-44.

Jia Q, Su W, Peng W, Li P, Wang Y. Anti-diarrhoea and analgesic activities of the metanol extract and its fractions of Jasminum amplexicaule Buch.-Ham. (Oleaceae). J Ethnopharmacol, 2008; 119:299 304.

Kromer W. Endogenous and exogenous opioids in the control of gastrointestinal motility and secretion. Pharmacol Rev, 1988; 40:121-162.

Martinez GJ. Recolección y Comercialización de Plantas Medicinales en el Departamento Santa María, Provincia de Córdoba, Argentina. Acta Farm Bonaer, 2005; 24 (4):575-584.

Mascolo N, Izzo AA, Capasso F. 1992. Castor oil-induced diarrhoea: involvement of nitric oxide. In: Capasso F, Mascolo N, eds. Natural drugs and the digestive tract. Roma: EMSI 123-127.

Mazzolin LP, Martiniano Nasser AL, Moraes TM, Santos RC, Nishijima CM, Santos FV, Varanda EA, Bauab TM, Machado da Rocha LR, Di Stasi LC, Vilegas W, Hiruma-Lima CA. Qualea parviflora Mart.: an integrative study to validate the gastroprotective, antidiarrheal, antihemorragic and mutagenic action. J Ethnopharmacol, 2010: 127:508514.

Mujumdar AM, Misar AV, Upadhye AS. Antidiarrhoeal activity of ethanol extract of the bark of Dalbergia lanceolaria. J Ethnopharmacol, 2005; 102:213-216.

Nansunga M, Barasa A, Abimana J, Alele PE, Kasolo J. Safety and antidiarrheal activity of Priva adhaerens aqueous leaf extract in a murine model. J Ethnopharmacol, 2014; 157:251-256.

OECD guidelines No. 423. Acute Oral Toxicity - Acute Toxic Class Method. Available at: http://www.oecdilibrary.org/docserver/download/9742301e.pdf [Accessed 18 November 2015]

Petri WA, Miller M, Binder HJ, Levine MM, Dillingham R, Guerrant RL. Enteric infections, diarrhoea, and their impact on function and development. J Clin Invest, 2008; 118:1277-1290.

Priestap HA, van Baren CM, Di Leo Lira P, Coussio JD, Bandoni AL. Volatile constituents of Aristolochia argentina. Phytochemistry, 2003; 63(2):221-225.

Rang HP, Dale MM. 2008. Aparato digestive. In: Rang HP, Dale MM, Ritter JM, Flower RJ, eds. Rang y Dale Farmacología. Barcelona: Elsevier 385-396.

Ratera EL, Ratera MO. 1980. Plantas de la flora argentina empleadas en medicina popular. Buenos Aires: Hemisferio Sur S.A. 
Robert A, Nezamis J, Lancaster C, Hanchar A, Klepper M. Enteropooling assay: a test for diarrhea produced by prostaglandins. Prostaglandins, 1976; 11(5):809-828.

Rouf ASS, Islam MS, Rahman MT. Evaluation of antidiarrhoeal activity of Rumex maritimus root. J Ethnopharmacol, 2003; 84:2001-2004.

Ruwart MJ, Klepper MS, Rush B. Clonidine delays small intestinal transit in the rat. J Pharmacol Exp Ther, 1980; 212:55-60.

Saggese A. 1959. Yerbas medicinales argentinas. Breves apuntes de las propiedades de las mismas e indicaciones de su uso. Argentina: Antognazzi y Cía.

Santos FA, Rao VSN. Quinine-induced inhibition of gastrointestinal transit in mice: possible involvement of endogenous opioids. Eur J Pharmacol, 1999; 364(2-3):193-197.

Sharkey KA, Wallace JL. 2012. Treatment of disorders of bowel motility and water flux; antiemetics; agents used in biliary and pancreatic diseases. In: Brunton NN, Chabner BA, Knollmann BC, eds. Las Bases Farmacológicas de la Terapeútica. Mexico: McGraw-Hill 1323-1350.
Trillo C, Arias Toledo B, Galetto L, Colantonio S. Persistence of the use of medicinal plants in rural communities of the Western Arid Chaco (Córdoba, Argentina). Open Complement Med J, 2010; 2:80-89.

UNICEF (The United Nations Children's Fund)/WHO (World Health Organization), 2009. Diarrhoea: why children are still dying and what can be done. Geneve.

Valle L, Puig M, Pol O. Effects of $\mu$-opioid receptor agonists on intestinal secretion and permeability during intestinal inflammation in mice. Eur J Pharmacol, 2000; 389:235-242.

\section{How to cite this article:}

Paredes JD, Sosa A, Fusco M, Teves MR, Wendel GH, Pelzer LE. Antidiarrhoeal activity of Aristolochia argentina Gris. (Aristolochiaceae) in rodents. J App Pharm Sci, 2016; 6 (02): 146152 . 